\title{
Re-actualization of Herritage of Surabaya in Social Studies Learning
}

\author{
By: \\ Eko Satriya Hermawan \\ Lecturer of History Education Program, Social and Law Faculty \\ Surabaya State University \\ Email: ekohermawan@unesa.ac.id
}

\begin{abstract}
evelopment of IPS learning media is still limited to the use of maps and power points, developed by teachers and students themselves. Teachers realize that in learning social studies (IPS) is needed the use of media learning, but because of the limitations of media owned schools so they rarely use the media as a supporter of the learning process. In addition to factors of facilities and infrastructure is also limited ability of teachers in making media and cost factors and time. This research used reseach and development ( $R$ \& $D$ ) approach, which was conducted in Surabaya. The result obtained showed the characteristics of IPS education as a synthetic discipline. IPS education not only synthesizes the concept of relevant concepts between educational sciences and the social sciences but also the purpose of education and development as well as social problems in social life will be a consideration of educational materials IPS. That the identity and context of children's social and culture plays an important role in the development of social studies.
\end{abstract}

\section{A. Introduction}

Cultural heritage is one of the global issues that became the focus of the world's attention, because it was set in 2003 as the "Year of Indonesian Heritage", (Indonesia Heritage Year 2003). This means it has been realized that preserving and preserving heritage (cultural heritage) is important to maintain identity. Referring to the statement then Surabaya Tempoe Doloe slogan underpin the development of the city of Surabaya the meaning of the city of Surabaya in the future, is a city that beridentitas and have the nobility of cultural values. Ancient relic artifacts were made part of urban development while maintaining the values and spirit that formed Surabaya city initially.

By realizing that the main "wealth" comes from its history, it is proper that the city of Surabaya maintains the preservation of cultural heritage, whether in the form of areas, buildings, and cultural activities such as art and tradition rooted in the history of the city. Therefore, efforts to revitalize the existing cultural heritages get priority scale (Ramdon, 2007). One of the efforts of Surabaya City Government to restore the face of the city of Surabaya is to re-promote the importance of revitalizing an area that is considered to have historical or historical value, becoming a Cultural Heritage which is protected by law. This is done because the number of objects or areas that have historical value keenanya very sadness.

Thus amidst the rich cultural treasures and historical sites of these historic buildings, the reality shows many problems and threats to the heritage or heritage. Of course this is an urgent matter to overcome so it needs to find the right solution quickly. For that we need the preservation of cultural heritage (cultural heritage).

The reality of learning so far is only a conditioning-conditioning process that does not touch the natural reality. Thus, most of the learners are unable to relate what they learn to how the knowledge will be used / utilized. In essence learners need knowledge and understanding of concepts related to the workplace and society in general where they will live and learn 
contextually and meaningfully, so as to apply knowledge and ability in their life. This is the meaning of contextual learning that learning materials will be meaningful if the students studying the subject matter presented have a student life context, so the lesson will become more meaningful and meaningful as well as fun. Therefore, Media in Social Studies has an important role.

\section{B. Theory and Method}

The tradition of Social Studies Taught as Social Science is a social learning mode that also develops good citizen character, characterized by the mastery of "mode of thinking from social science disciplines; that this mode of thinking is generalizable; and learned that he would understand properly, appreciate deeply, infer carefully, and conclude logically "(Barr, et al, 1973: 23-24). This is based on the belief that "... if a student acquires the habit of mind and the mind of the pattern of social science discipline, he will more discriminating, make better his as well as social policy decisions, and ultimately understand the structure and the process of our society "(Barr et al, 1978: 71). In other words, this tradition focuses on the development of good citizen character, characterized by its ability to see and solve social and personal problems by using the vision and workings of social scientists.

On the other hand the tradition of "Social Studies Taught as Reflective Inquiry" is a social learning mode that emphasizes the development of good citizens with different criteria, that is, from their ability to "clarify their own value structure" Barr et al, 1978: 27). Therefore the main purpose of this tradition is "... .the enhancement of the students 'decision making abilities, for decision making is the most important requirement of the students' decision making abilities, for decision making is the most important requirement of citizenship in a political democracy "(Barr et al, 1978: 111). In other words, this tradition focuses on developing the character of good citizens with the basic character of being able to make decisions in a socio-political context.

This research uses research and development approach. Borg and Gall (1983: 772) say "educational research and development $(R \& D)$ is a process used to develop and validate educational production". The series of research and development begins with explorations and conceptual studies, followed by testing and evaluation, and implementation. The second year step and so on is done by referring to the result of the previous step so that in the end a new educational product is obtained.

This research was conducted at Junior High School of Surabaya. namely in SMP Negeri 1,2 , dan 4 . The subject of this research is the students of class VII. Students are involved as research subjects starting pre-survey (preliminary study), limited trials, broad trials, empirical validity and after empirical validity. Teachers are included as research subjects during presurveys, limited trials, extensive trials, empirical validation, and post empirical validation. Principal or Vice Principal is involved as a research subject during pre-survey

\section{RESEARCH RESULTS \\ 1. Characteristics of IPS Learning}

IPS education is more emphasized on how to teach about the social sciences or more to the application (application of knowledge social studies). The science presented in IPS education is a synthetic between the social sciences and the science of education. IPS education is the result of "inter cross" and "trans disciplinary" engineering between educational disciplines with pure social disciplines for educational purposes.

Characteristics of IPS education as a synthetic discipline (Somantri, 2001: 198) because IPS education not only synthesizes the concept of relevant concepts between education sciences and the social sciences but also the goals of education and development and social 
problems in social life will be consideration of IPS education materials. As Noffke (2000: 78) points out that the child's social and cultural identity and context plays an important role in the development of an IPS curriculum rather than a "universal" curriculum. The development of the IPS curriculum should be child-centered and should be seen as part of community life and social movements that reflect the struggle for social justice.

\section{Characteristics of Herritage}

Some studies related to Laweyan and Kauman areas as batik centers are mostly aimed at tourism development in Surabaya. Because of that the result is less berkonstribusi to education in school. This research is a development of research results that have been conducted researchers since 2002 -20012. Sariyatun (2002) in his research entitled Existence of Chinese Batik Entrepreneur of the early 20th century, explaining that from a historical perspective since the early 20th century Surabaya has become a central area batik batik and trade Surabaya has reached the area of Sumatra and Malaka.Sebagai Vorstelanden area Surabaya batik famous with classic batik motif containing guidance and order. Javanese batik traders in the late nineteenth and early twentieth centuries established large businesses and shelters in the city. the first Islamic-national pattern organization in Indonesia by Haji Samanhudi, Sarekat Dagang Islam on October 16, 1905. The former glory of indigenous batik traders can be seen from a number of luxury homes in Jalan Raj Raj, its glory by competing to build a luxurious big house with beautiful architecture but protected by high fences with gates ("regol") is great (Sariyatun, 2002).

The results of this study indicate that at the beginning of the twentieth century Kauman and Laweyan area is the center of batik. Laweyan village is well known as a rich merchant residence associated with the rope and batik business. The walls of their tall and large houses are visible everywhere. The spacious courtyard is surrounded by thick, high, and strong brick walls like the walls of a palace. There are many opinions about Laweyan society that are associated with a strong picture of trade, working for their own interests, and becoming merchants. Something very far from honor and prestige as a king or king's servant. The greatness, the glory of their status, the good and the bad, is determined by their wealth.

In the context of classical batik in relation to education put forward the results of Leo Agung.s Research. (2010). Development of Local Content Learning Model in Secondary School Based on Cultural Advantages of Classical Batik Art of Surabaya as Cultural Heritage Preservation. The results showed that there is no similar perception between the schools in Surabaya about the implementation of local content teaching batik art. There are schools that fall into socio-cultural subjects, but there are also those who place as extra-curricular activities; second, the understanding of art and culture teachers about classical batik art is quite good. . Third, the lack of ability of teachers in preparing learning strategies and implementation of teaching and learning process local content of batik art.

Research on the values of other classical batik culture done Sariyatun (2012) entitled IPS Learning Modes in SMP Based on Local Values of Surabaya Classical Batik Culture to Improve the Nation. The results show that in the Javanese tradition, batik motif relates to all stages of human life from birth to death. Cultural values derived from classical batik motifs are basically derived from ethos and aesthetics as well as aspects of the life view of the Javanese priyayi, emphasizing the need for respect for hierarchical order as a first step in human journey to God. the transformation of priyayi cultural values (Javanese) in classic batik motifs is also based on the order (hierarchy and harmonization) and the guidance related to the self, its relationship with God, the relationship with other people, the society and the nation and the relationship with the environment.

Some of these studies focus on the development of values derived from classical batik motifs for character in education. Area "Kampoeng Batik" has not been used as a medium of 
learning. Therefore it is necessary to develop a model of IPS-based learning media visualization Kampoeng Surabaya area as a media to grow entrepreneurship spirit and as a revitalization of cultural heritage.

People and settlements are two things that are not separated from each other, the settlement of a society tends to be grouped, because human nature as social beings basically they live their lives in groups with community groups. Settlements of settlements can be based on commonalities in society, such as the grouping of settlements from certain social layers, groupings of settlements from certain professions and groupings of settlements on the basis of certain ethnic groups (Widayati, 2002).

The arrival of the Dutch colonials influenced the cities and settlement patterns in Java Island, this is due to the rapid population increase in a relatively short time in urban Java, including in Surabaya. Facilities and old city infrastructure is no longer able to accommodate the population growth and progress of the times. In addition, the settlement pattern arrangement of the population is done to anticipate a conflict between the population (Handinoto, 1996)

The structure of the colonial city has actually been planned and grown on the assumption that ethnic origin and ethnic origin are the main principles of social organization. The ethnic separation system is combined with the specificity of the settlement, both within and within the ethnic group. Despite the concentration of high and low social status in each group, there has never been a complete mixing between ethnic and social classes. Because the segregation of settlements is the basic guideline, people of the same ethnic group but different socioeconomic statuses tend to stay close (Prejudice, 2010).

Surabaya is a traditional royal city that has heterogeneous population of various tribes and cultures, the presence of Dutch Colonial in Surabaya influences the grouping of settlement patterns based on ethnic similarities.

\section{Ideal IPS Learning by utilizing Cultural Herritage}

While Morrissett and Haas (1982), including conservative groups mention the purpose of social studies are cultural continuity, intellectual aspects of history and social science and reflective thinking process. Both researchers agree that social research is used for three main purposes: (1) socialization of community norms, (2) transmission of facts, concepts, and generalizations and (3) promotion of critical or reflective thinking.

Through a reflective and critical learning process will be achieved IPS educational goals that emphasize (1) the growing value of citizenship, morals, state ideology and religion; (2) content and methods of thinking scientists; (3) reflective inquiry. In accordance with this goal, IPS education is directed to guide learners in social behavior (behavior), encourage the formation of motivation and attitudes (attitude), preparing skills or a particular social relationship (skill), and increase the knowledge of knowledge (knowledge ) so that every citizen has a high sense of concern and commitment, responsible and critical to the self and the social and environmental environment that affect the life situation both locally and globally. By mastering social knowledge is expected learners can think reflectively, critically, and able to make decisions wisely and precisely.

Thinking reflectively and critically in Social Studies, according to Farisi (2005: 54-56) is based on: first, the thinking of Hunt \& Metcalf (1955) that PIPS is expected to educate students to develop decision-making ability carefully, maximize the chance of learners to make decisions intelligent, reasoning based on what is believed and guide them to accept ideas and guide them in determining further lenbih actions. Secondly, PIPS needs to be directed to clarify the value, ie the ability of learners in conducting value purification; Third, PIPS needs to be directed to social action, related to environmental competence. According to Newmann environmental competence is a knowledge skill that allows learners to have the ability to influence their environment. Fourth, PIPS is directed to the development of reasoning (moral reasoning) that 
helps and facilitate learners in developing reasoning and moral considerations, so gradually reach higher levels. Fifth, PIPS needs to be directed to social studies and political policy (social and political policy analysis) or social and political engagement. This idea developed from the philosophy and science of jurisprudence of Oliver and Shaver which Newmann later developed for his conception of "social action" (Stanley 1985: 313). Sixth, PIPS needs to develop an attitude of "social critisism" (social critisim) initiated by Engle. This thinking is based on the assumption that change and reform are a natural tendency for mankind.

\section{E. Conclusion}

Surabaya is a traditional royal city that has heterogeneous population of various tribes and cultures, the presence of Dutch Colonial in Surabaya influences the grouping of settlement patterns based on ethnic similarities. Seeing the pattern of settlements established by the Dutch Colonial, in general settlements in the region of Surabaya is divided into six specific areas. These areas are located around the palace, because the palace is the focal point. This is reinforced by Widayati's opinion that "macro area of Surabaya city can be divided into several specific space units, namely Chinatown, Arab Region, Santri Region, Ningrat Area, Pejagalan Area, and Artisan Area" (2002: 8).

The theoretical basis of media development that is first, IPS is the subjects that are expected to play a role in the formation of good citizenship attitude, as well as a reflective effort that IPS education can be used as a critique of social life (social studies as social criticism). Through IPS education will develop the ability to think critically (Critical thinking) personal development (social studies as personal development of the individual, and equip one's ability in self-development through various social skills in life).

\section{BIBLIOGRAPHY}

Arief S Sadiman, dkk. 2011. Media Pendidikan. Jakarta: Rajawali.

Banks, J. (1990). Teaching Strategies for the Social Studies. New York \& London: Longman.

Barr, R., Shermis, S. \& Barth, L.J. (1978). The Nature of the Social Studies. California: ETC Publications, Palm Spring.

Barth, J.L. 1990. Methods of Instructional in Social Studies Education ( ${ }^{\text {rd }}$ Ed). lanham: Univerrsity Press of America.

Gall, M.D., Gall, J.P., Borg, W.R. 1983. Educational Research. Boston: Pearson Education, Inc.

Gardner, Howard. (2004). How Education Changes:Considerations of History, Science, andValues,"( Edited ) Marcelo M. Suárez-Orozco and Desirée Baolian Qin-Hilliar. Berkelyy Los Angeles London: University of California

Giroux, H. A. (1996). Is there a place for cultural studies in colleges of education? In H. A. Giroux, C. Lankshear,

Moh Numan Sumantri. 2001. Menggagas Pembelajaran Pendidikan IPS. Bandung: Remaja Rosdakarya.

Nana Sudjana dan Ahmad Rivai. 2010. Media Pengajaran. Bandung: Sinar Baru Algensindo.

Sapriyatna. 2009. Pendidikan IPS. Bandung : PT Remaja Rosda Karya

Sariyatun (2001). Eksistensi Wirausaha Batik Cina di Solo Awal Abad XX, Dalam Usul Penelitian. Surakarta: LPP - UNS. 
Sariyatun (2006.) Pengembangan Model Revitalisasi Seni Batik Klasik Melalui Interpretasi Sebagai Upaya Untuk Melestarikan Warisan Budaya danMendukung Pengembangan Pariwisata. Dalam Laporan Penelitian. Hibah. Surakarta: LPP - UNS.

Sariyatun (2007), Pengembangan Model Revitalisasi Seni Batik Klasik Melalui Interpretasi sebagai Upaya untuk Melestarikan Warisan Budaya dan Mendukung Pengembangan Pariwisata di Surakarta, Laporan Penelitian Surakarta UNS

Sumaatmadja, Nursid..2002. Pendidikan Pemanusiaan Manusia Manusiawi. Bandung : Alfabeta.

Supriatna Nana.2007. Pembelajaran Sejarah Berorientsi Pada Masalah-Masalah Kontemporer. Disertasi tidak diterbitkan. Bandung: Program Pascasarjana. Universitas Pendidikan Indonesia

Wiggins, Haley. 2004.A Learner-centered and participatory approach to teaching community. New York \& Burlingame : Harcourt, Brace \& World, Inc.

Widayati, Naniek.2002.Permukiman Pengusaha Batik Di Laweyan Surakarta. Disertasi Program Pascasarjana Fakultas Sastra Universitas Indonesia. Jakarta.

Wiggins, Haley. 2004.A Learner-centered and participatory approach to teaching community. New York \& Burlingame : Harcourt, Brace \& World, Inc. 